\title{
PUBLIC PARTICIPATION IN IMPLEMENTATION OF STRATEGIC POLICY: A CASE STUDY OF RANONG PROVINCE
}

\author{
Bioriboon Chalong
}

Suan Sunandha Rajabhat University, Bangkok, Thailand

The objective of this research is to examine the participation level of the Ranong Province residents in implementation of the local Strategic Policy. The results will lead to recommendations related to better participation of residents. The population of this study is residents of the Ranong Province. The sample size is 400 and the data has been collected using questionnaires. In-depth interviews have been also conducted to explore the opinions of the local leaders and related government officials. The data have been analyzed to see the statistical impacts. The research study is expected to find the relationship between independent variables which are Gender, Age, Level of education, Career, Level of Income and Religion, and the dependent variable which is the participation of residents in implementation of the strategic policy.

Keywords: public participation; strategic policy; public policy; Ranong Province; Thailand.

\section{Introduction}

Public participation is a political principle or practice which may be also recognized as a right. The term "public participation", often called P2 by practitioners, is sometimes used interchangeably with the concept of stakeholder engagement and/or popular participation. Most experts state that population usually has a strong interest in the outcomes of policy choices, and in design and implementation of a variety of public policies as well as in the institutions delivering them.

Yet overall, the level of public participation and citizen engagement in these decisionmaking processes tends to be low. The public or "citizens" are often very little informed about what is being discussed and decided, even though it is supposed to be "in the public interest". This is also the case of what, in developing countries, is the most fundamental expression of the sociopolitical contract between state authorities and citizens: the constitution.

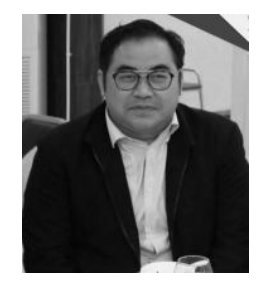

\section{Boriboon Chalong}

Master of Public Administration

Lecturer in Suan Sunandha Rajabhat University, Bangkok, Thailand

Researcher in Faculty of Political Science, Thammasat University, Bangkok, Thailand

Expert of National Economic and Social Advisory Council Thailand

Science interests: national policy, legislative system, Governance, economy regulation

E-mail: Boriboon.ch@ssru.ac.th 


\section{PUBLIC PARTICIPATION IN IMPLEMENTATION OF}

On the other hand, there is the so-called "security sectors" since numerous adviser consider "security sector reform" a matter of "specialists," even though public security is often a major preoccupation of citizens.

In Thailand, the public participation principle is mentioned in The Constitution of the Kingdom of Thailand, as of 1997 . To contribute to the existing literature, the study adopts the theoretical model from the study of Cohen (1977) to examine and analyze the relationship between demographic variables, democratic knowledge and attitude towards democracy with the level of participation in the Ranong Province ofThailand.

\section{Objectives}

The research is to examine the relationship between demographic variables, democratic knowledge and attitude towards democracy with the factors and the level of public participation among the Ranong Province residents regarding strategic policy and its implementation.

\section{Literature review}

\section{The Concept of Public Participation}

Participation is the process through which stakeholders influence and share control over priority setting, policy-making, resources' allocation and access to public goods and services (World Bank Group, 2005). Participation in planning is widely considered to improve the quality and effectiveness of decision-making as it widens the knowledge base, stimulates creativity and creates social support for policies (Pretty et al., 1995; Pelletier et al., 1999; Monnikhof and Edelenbos, 2001; Burby, 2003; Leeuwis, 2004). Participation means involvement in a decision-making processes of individuals and groups that are either positively, or negatively affected by a planned intervention (e.g., a project, a program, a plan, a policy) or are interested in it (Andre et al., 2006). It acknowledges that the public has the right to be informed early and to be proactively involved, in a meaningful way, in the proposals which may affect their livelihoods.

\section{The Importance of Public Participation}

It is widely believed that public participation contributes to better projects, better development and collaborative governance. However, traditional forms of (ex-post) public involvement like information and court appeal typical for the so-called "decide-announcedefend" style policy-making, have often proven inadequate, as they institutionalize hindrance power in legislative procedures and do not allow for (ex ante) constructive contributions to planning. In most of Western countries more constructive and cooperative forms of planning, like consultation and active, early involvement are now supported and actively promoted, for instance, by the EU member states (WFD, Art.14).

Research has shown that these forms of participation can be advantageous for the speed and quality of implementation of planned decisions, but not without some pitfalls (Davies, 2001; Klijn and Koppenjan, 2003; Enserink and Monnikhof, 2003; Pahl-Wostl, 2002). This especially concerns strategic planning, discussions about plans, policies and programmes at the national level of institutionalized and well-organized stakeholder groups who are 
considered as partners in the planning process and procedures for National Security Policy Planning.

\section{The Process of Public Participation}

Public Participation Best Practices Principles are listed in many documents published online. We can suggest the following list of core values important for the practice of public participation:

The public should have a say in decisions that affect their livelihoods, it has the right to be informed early and be proactively involved in a meaningful way;

Participants should get all information they need to participate in a meaningful way to increase the interest and motivation to participate; this includes the promise that the public's contribution will actually influence the decision;

The public participation process should respect the historical, cultural, environmental, political and social backgrounds of the communities which might be affected by a proposal. Inclusiveness of participation should cover less represented groups like indigenous peoples, women, children, the elderly, and poor people;

The public participation process involves participants in defining how they participate and promote equity between actual and future generations in the context of sustainability.

In respect to such governance principles, public participation should be:

- Initiated very early in a life cycle of a planned intervention, and sustained during its entire life cycle.

- Well planned and structured. All actors should know the aims, rules, organization, procedures and expected outcomes of the PP process undertaken.

- Tiered and optimized. Any PP program should take place at the most efficient level of decision-making, e.g. at the policy, plan, program or project level.

- Led by the neutral authority in its formal or traditional sense and follow the rules known and accepted by all the parties concerned. PP also needs to follow the usual rules of ethics, professional behavior or moral obligations.

- Focused on the negotiable issues relevant to the decision-making. Because consensus is not always feasible, PP needs to consider all possible values and interests of all potential participants, and then to focus on the negotiable issues.

As we can read in Palerm (2000), public participation has been increasingly recognized as one of the most important aspects for environmental impact assessment. Different forms and levels of participation might be relevant for different phases in implementation of national security policy. In order to be effective, public participation should be well organized and well managed.

Some studies on the level of people participation have been based on the socalled Ladder of Citizen Participation by Sherry R. Arnstein.

Sherry R. Arnstein (1969) suggested a typology of eight levels in participation that may help with analysis of this rather confusing issue. For illustrative purposes, the eight types are arranged in a ladder pattern with each rung corresponding to the extent of citizens' power in determining the end product. The bottom rungs of the ladder are: (1) Manipulation and (2) Therapy. These two rungs describe the levels of "non-participation" that have been contrived by some to substitute for genuine participation. Their real objective is not to enable people to participate in planning or conducting programs, but to enable power holders to "educate" or 


\section{PUBLIC PARTICIPATION IN IMPLEMENTATION OF}

"cure" the participants. Rungs 3 and 4 progress to the levels of "tokenism" that allow the have-nots to hear and to have a voice: (3) Informing and (4) Consultation.

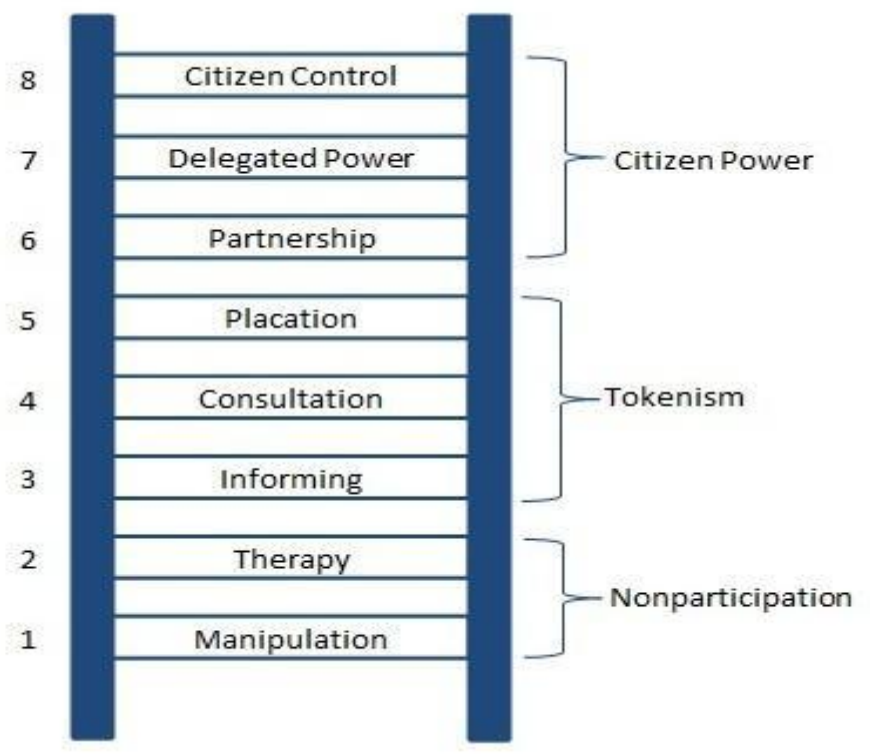

Figure 1. The Ladder of Citizen Participation

(Source: Arnstein, 1969)

When they are preferred by power holders as the total extent of participation, citizens may indeed hear and be heard. But under these conditions they lack the power to insure their views will be heeded by the powerful. When participation is restricted to these two levels only, there is no follow through; no "muscle" involved, hence, no assurance of changing the status quo. Rung (5) - placation, is simply a higher level tokenism because the ground rules allow have-nots to advise, but retain for the power holders the continued right to decide. Further up the ladder are the levels of citizen power with increasing degrees of decisionmaking clout. Citizens can enter into a (6) Partnership that enables them negotiate and engage in trade-offs with traditional power holders. At the topmost rungs, (7) Delegated Power and (8) Citizen Control, have-not citizens obtain the majority of decision-making seats, or full managerial power.

Obviously, the eight-rung ladder is a simplification, but it helps with illustrating the point that so many have missed: that there are significant gradations of citizen participation. Knowing these gradations makes it possible to cut through the hyperbole to understand the increasingly strident demands for participation from the have-nots as well as the gamut of confusing responses from the power holders.

Sunee Mulligaman (2002) divides the level of public participation into 6 levels: (1) Sharing government, (2) Join the discussion, (3) Joint decision-making, (4) Cooperate, (5) Follow up, monitoring, evaluation, and (6) Get Results.

John M.Cohen and Norman T Uphoff (1977) classified participation into 4 categories:

1) Decision Participation that consist of 3 steps: the beginning of decision, the process of decision and the performance of decision;

2) Performance Participation that includes resources' administration and cooperation;

3) Sharing material benefits, social benefits or individual benefits;

4) Evaluation Participation. 


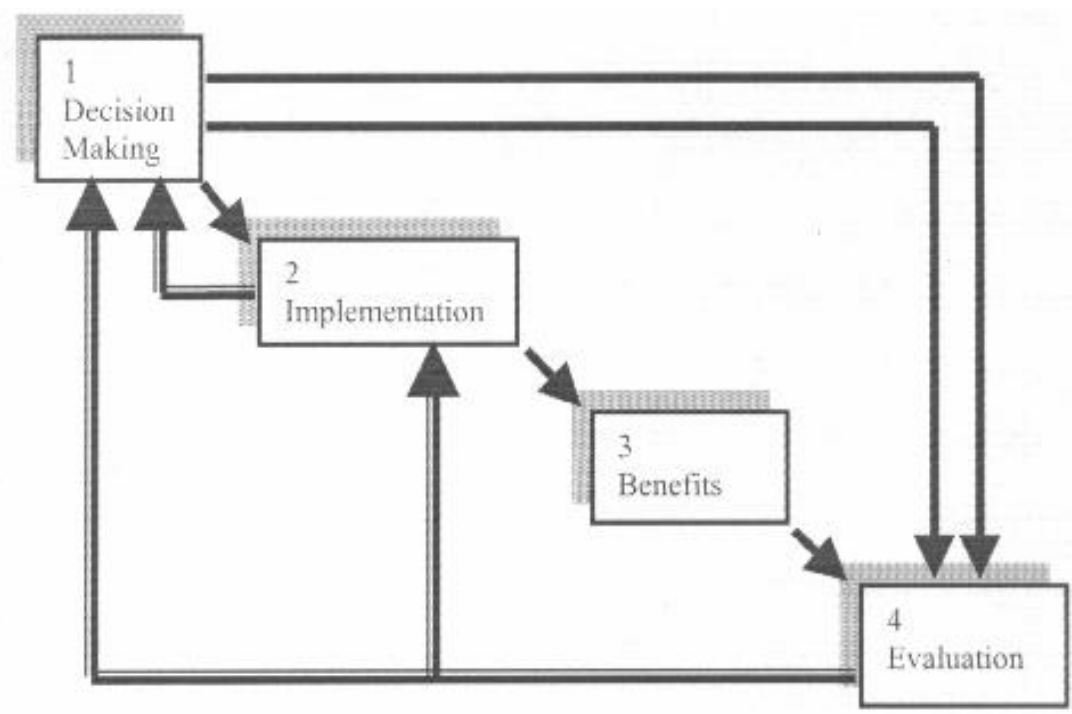

Figure 2. Four categories of participation.

(Source: Cohen, 1977)

\section{Methodology}

A questionnaire was constructed and administered among the Ranong province residents.The Likert five-point scale was applied to investigate the factors influencing the level of public participation from the perspective of the Ranong province residents.

The population (191,868 (as of 2018)) included all in the Ranong province, Thailand. The simple random sampling technique was performed to obtain a sample group that included 400 residents.

Taro Yamane (1973) technique was utilized to obtain an accurate sample group. The dependent variables of this study included the demographic variables, democratic knowledge, and the attitude towards democracy. The independent variable is the level of public participation, as in (Cohen \& Uphoff, 1977).

Descriptive statistics utilized in this research included percentage, mean, and standard deviation. In addition, 30 pilot questionnaires were tested, each question had to pass the Cronbach Alpha criteria with the value of at least 0.7 Moreover, validity of the questions was evaluated by means of using the IOC technique with three experts.

\section{Results}

The total of 400 residents was chosen in the Ranong province of Thailand. The findings of this study have revealed the following:

Tab. 1 shows the participants' demographics. There was a roughly even distribution of men and women (52\% to $48 \%$ ). The majority of the participants were around 30-59 y.o., this group was comprising approximately half of the total sample. The average level of education (42.25\% of all respondents) is high-school education. Most of the respondents were either employees at some businesses, or involved in agricultural activities. The average income of the surveyed households is reported to be at the level of 5,001-1000 Baht per month 


\section{PUBLIC PARTICIPATION IN IMPLEMENTATION OF}

(48.75\%). Finally, $94.50 \%$ of the respondents are Buddhists; only $4.35 \%$ are Muslim and even less, $1.15 \%$ are Christians.

Table 1. Demographic Characteristics of the Respondents

(Source: made by the author)

\begin{tabular}{|c|c|c|}
\hline Demographics & Sample $(\mathrm{N}=400)$ & Percentage \\
\hline Gender & $\begin{array}{l}\text { Male } \\
\text { Female }\end{array}$ & $\begin{array}{l}52.0 \\
48.0\end{array}$ \\
\hline Age & $\begin{array}{l}\text { Less than } 20 \\
20-29 \\
30-39 \\
40-49 \\
50-59 \\
60+\end{array}$ & $\begin{array}{c}10.50 \\
18.25 \\
21.25 \\
24.25 \\
16.25 \\
9.50\end{array}$ \\
\hline Level of Education & $\begin{array}{l}\text { Elementary education } \\
\text { High school education } \\
\text { Bachelor's degree }\end{array}$ & $\begin{array}{l}16.00 \\
42.25 \\
35.25\end{array}$ \\
\hline Career & $\begin{array}{l}\text { Master's degree } \\
\text { Other } \\
\text { Civil Servant } \\
\text { State Enterprise Employee } \\
\text { Company owner } \\
\text { Employee } \\
\text { Student } \\
\text { Agricultural worker } \\
\text { Merchant } \\
\text { Other }\end{array}$ & $\begin{array}{c}5.25 \\
1.25 \\
15.75 \\
13.50 \\
7.50 \\
18.00 \\
12.25 \\
16.25 \\
13.75 \\
3.00\end{array}$ \\
\hline $\begin{array}{l}\text { Level of Income } \\
(32 \text { Baht = US\$1) }\end{array}$ & $\begin{array}{l}\text { Less than } 5,000 \\
5,001-10,000 \\
10,001-20,000 \\
20,001-30,000 \\
30,001-40,000 \\
40,001-50,000 \\
\text { More than 50,000 }\end{array}$ & $\begin{array}{l}10.25 \\
48.75 \\
26.25 \\
10.50 \\
2.00 \\
1.75 \\
0.50\end{array}$ \\
\hline Religion & $\begin{array}{l}\text { Buddhism } \\
\text { Islam } \\
\text { Christianity } \\
\text { Other }\end{array}$ & $\begin{array}{l}94.50 \\
4.35 \\
1.15 \\
0.00\end{array}$ \\
\hline
\end{tabular}


Table 2. Public Participation

(Source: made by the author)

\begin{tabular}{|l|c|c|c|}
\hline Level of Participation & Mean & S.D. & Rank \\
\hline Variables & & & \\
\hline 1. Sharing & 4.0 & 0.955 & 1 \\
\hline 2. Performance Participation & 4.42 & 0.845 & 2 \\
\hline 3. Decision Participation & 4.38 & 0.780 & 3 \\
\hline 4. Evaluation participation & 4.05 & 0.755 & 4 \\
\hline
\end{tabular}

The hypotheses testing about the relationships between democratic knowledge and attitude towards democracy are shown in the tables below. Tab. 3.

The relationship between democratic knowledge and public participation is shown in

Table 3. Relationship between Democratic Knowledge and Public Participation (Source: made by the author)

\begin{tabular}{|l|c|c|c|c|}
\hline \multirow{2}{*}{ Democratic Knowledge } & \multicolumn{3}{|c|}{ Levels of Participation } & \multirow{2}{*}{$\begin{array}{c}\text { Total } \\
\text { (persons) }\end{array}$} \\
\cline { 2 - 4 } & High & Medium & Low & 164 \\
\hline High & 76 & 59 & 29 & 120 \\
\hline Medium & 65 & 38 & 17 & 116 \\
\hline Low & 34 & 66 & 16 & 400 \\
\hline Total (persons) & 175 & 163 & 62 & 40 \\
\hline
\end{tabular}

From the above table we can state that democratic knowledge has a significant relationship with the level of public participation.

Table 4. Relationship between Attitude towards Democracy and Public Participation (Source: made by the author)

\begin{tabular}{|l|c|c|c|c|}
\hline \multirow{2}{*}{$\begin{array}{l}\text { Attitude towards } \\
\text { democracy }\end{array}$} & \multicolumn{3}{|c|}{ Levels of Participation } & \multirow{2}{*}{$\begin{array}{c}\text { Total } \\
\text { (persons) }\end{array}$} \\
\cline { 2 - 4 } & High & Medium & Low & 159 \\
\hline High & 78 & 53 & 28 & 122 \\
\hline Medium & 65 & 38 & 19 & 119 \\
\hline Low & 35 & 66 & 18 & 400 \\
\hline Total (persons) & 178 & 157 & 65 & \\
\hline
\end{tabular}

The findings from the above tables also reveal that attitude towards democracy is an important variable for explaining the level of public participation. This is especially the case of Ranong Province, as according to our data on this province, both these variables are playing a significant role and influence the level of public participation of the local residents. 


\section{PUBLIC PARTICIPATION IN IMPLEMENTATION OF}

\section{Conclusions and Discussion}

This study has examined and analyzed the relationships between democratic knowledge and attitude towards democracy on the one hand with the level of public participation on the other. The findings of our study have both theoretical and applied implications for public participation process as such and studies in this field. Understanding the variables that are influencing residents' participation level can help local authorities and policymakers better assess residents' involvement in strategic policy implementation at its different stages. Furthermore, it is encouraging to see that the residents are so well aware of the strategic policy as such.

\section{Suggestions}

This study is not without its limitations, of course. As mentioned previously, the small sample size could have led to subjective opinions and some bias. Additional qualitative research study with key informants can produce supporting findings, but it still cannot represent the whole population.

Future studies could pursue the same line of enquiry through alternative quantitative surveys. Secondly, as the level of public participation is likely to vary in time, it is important to revisit the same area in the future to determine changes in the local residents' participation.

\section{Acknowledgement}

The author would like to thank the Research and Development Institute, Suan Sunandha Rajabhat University, Bangkok, Thailand for the provided financial support.

\section{References:}

Andre, P., Delisle, C.E. \& Reveret, J.P. (2004). Environmental Assessment for Sustainable Development: Processes, Actors and Practice. Presses Internationales Polytechnique, Montreal.

Arnstein, Sherry R. (1969). A Ladder of Citizen Participation. JAIP, 35,4: 216-224.

Burby, R. J. (2003). Making plans that matter, citizens' involvement and government action. Journal of the American Planning Association. 69: 33-47.

Campbell, D. J. (2008). The basic concept for the democracy ranking of the quality of democracy. Democracy Ranking. Vienna, Austria.

Cohen, J. M. \& Uphoff, N. (1977). Rural Participation: Concepts and Measures for Project Design, Implementation and Evaluation. In: Rural Development Monograph. 2 The Rural Development Committee Center for International Studies, Cornell University, January.

Davies, A. (2001). What silence knows - planning, public participation and environmental values. Environmental Values. 10: 77-102.

Enserink, B. \& Monnikhof, R.A.H. (2003). Impact assessment and public participation: facilitating co-design by information management - an example from The Netherlands. Journal of Environmental Planning and Management. 46,3: 315-44.

Klijn, E.H. \& Koppenjan, J.F.M. (2003). Rediscovering the citizen: new roles for politicians in interactive policy making, In: McLaverty, P. (Ed.), Public Participation and Innovations in Community Governance. Ashgate, Aldershot: 141-164. 
Leeuwis, C. (2004). Communication for Rural Innovation, Rethinking Agricultural Extension. Blackwell Publishing, Ames, IA.

Monnikhof, R. \& Edelenbos, J. (2001). Into the fog. Stakeholder input in participatory impact assessment, impact assessment and project appraisal. Journal of the International Association for Impact Assessment.19,1: 29-39.

Pahl-Wostl, C. (2002). Participative and stakeholder-based policy design, analysis and evaluation processes. Integrated Assessment, 3: 3-14.

Pelletier, D., Kraak, V., McCullum, C., Uusitalo, U. \& Rich, R. (1999). The shaping of collective values through deliberate democracy: an empirical study from New York's North Country. Policy Science, 32: 103-131.

Pretty, J.N., Guijt, I., Thompson, J. \& Scoones, I. (1995). Participatory Learning and Action. A Trainer's Guide, International Institute for Environment and Development (IIED), London.

Sharon, S. \& Saul, M. (1996). Social psychology. Boston: Houghton Mifflin.

Stipack, A.Y. (1979). Government spending and economic growth. Journal of Applied Economics, 26 (1): 46.

World Bank Group (2005). Poverty reduction, strategy formulation organizing participatory processes in the PRSP. What is participation and what role can it play in the PRSP? Available at: www.worldbank.org/participation/PRSP/what.htm .

Yamane, T. (1973). Statistics: An Introductory Analysis. New York: Harper and Row.

Paper submitted

Paper accepted for publishing

Paper published online
11 April 2019

12 July 2019

08 August 2019 